\title{
Intertextuality as a Catalyst for Ideology Formation: A Study of Media Discourse Dynamics
}

\author{
Najma Qayyum ${ }^{1}$ \\ ${ }^{1}$ Department of English, National University of Modern Languages, Islamabad, Pakistan \\ Correspondence: Najma Qayyum, Lecturer \& PhD Scholar, Department of English, National University of \\ Modern Languages, Sector H-9, Islamabad, Pakistan. E-mail: nqayyum@numl.edu.pk
}

Received: March 14, 2019 Accepted: April 10, 2019 Online Published: May 8, 2019

doi:10.5539/ijel.v9n3p249 URL: https://doi.org/10.5539/ijel.v9n3p249

\begin{abstract}
This article investigates how intertextuality in media discourse works as an ideological catalyst. It explores how discursivity and intertextuality in media discourse permeate all levels of society and shape the social and political ideologies of the readers. Media discourse producers are both politicians and reporters. The article investigates how they use language as a manipulating tool. The article also discovers how intertextuality is created in media discourse by clipping specific linguistic elements of different discourses and then forging them together for effect. Four Pakistani English daily newspapers have been analyzed which were selected through non-probability sampling method. The study is qualitative in nature and spreads over six months that is from March 2013 to August 2013. The tenets of critical discourse analysis (CDA) were employed as the main research tool. For understanding the linguistic aspects, Fairclough's (1995) idea of texts and genres was used and for interpreting the contextual use of language, Halliday's ideas of field, tenor and mode were incorporated. The analyses revealed how politicians as well as reporters instill tacit ideas into the minds of their addressees which blur and downplay their thinking pattern and entice them to think and behave the way these discourse producers want them to.
\end{abstract}

Keywords: intertextuality, media discourse, discursivity, manifest intertextuality, constitutive intertextuality

\section{Introduction}

Newspapers are the most widely-read types of written discourse. The discourse in newspapers is known as media discourse. It carries some specific features that make it a distinct text form. Mauranen (1993) and Swale (1993) describe that the only purpose of a newspaper is to deliver information which demands the reporters to be totally objective. This ideal of detachment is achieved by using techniques such as direct quotes and actual lexical items in the discourse. Sometimes, the same purpose is achieved by quoting somebody else's opinion in order to convince and persuade the readers. According to Allen (2003), readers do not create meanings instead a complex network of texts invoked during the reading process creates them. This phenomenon is termed as intertextuality which serves as a meaning-making tool. Intertextuality also implies that no text is completely original, produced in its own right.

The study uncovers the tactics employed in media discourse that form and shape public opinion. For a comprehensive understanding of the media discourse as used in newspapers, the researchers and readers need to know how intertextuality permeates the texts in media discourse and how multiple voices add to the overall meaning (Fairclough, 1995).

No text is truly original. Hence, whatever exists in newspapers is a hybrid discourse as it is the result of mixing different ideas and texts. The pervasiveness of intertextuality subtly affects and renders the overall thinking pattern of the readers. Hence, it acts as a catalyst for forming specific ideologies.

Dijk (1998) talks about different ways of organizing, maintaining and stabilizing power relations. He points out otherness in media discourse as one such technique. He says that it can be in the form of binaries like Us/Them (the relationship between the rulers and the ruled for which Marx uses the term 'contradictory essential relation'). Dijk also elaborates on how these power relations are maintained through intriguing techniques. The politicians usually exploit such a situation where ideology is shrouded in intrigue and mystery.

Ideology can even take a religious form and thus finds its way into the lives of commoners. Newspapers play an important role in presenting a broader ideological stance by projecting some issue and undermining others by using some strategies. Gition (2003) says that in today's world, no institution is free of hegemonic functions. He 
describes media to be a corporate sector whose sole function is to safeguard the interests of the elite. The rationale for the study is to familiarize the readers with the techniques used in media discourse and to equip them with critical abilities so that they can interpret the ideas implicit in different texts and thus can have some control over their thought pattern.

\subsection{Research Questions}

1) Which linguistic techniques are employed in media discourse for promoting specific political ideologies?

2) Which elements of different discourses have been used for intertextual connectivity?

\subsection{Research Objectives}

For discovering answers to the research questions, these objectives were set:

- To investigate the linguistic strategies used by the media discourse producers which entice the discourse receivers to think and act in specific ways

- $\quad$ To explore the features of media discourse that result in intertextuality

\section{Literature Review}

Intertextuality means presence of other texts in a discourse. Bakhtin (1981) identified this dialogic nature of texts. According to him, one cannot rely on one text for understanding the entire meaning of a text. Thus, he was the one who initiated the concept of intertextuality. Julia Kristeva (1966) is often credited for the term but the fact is that she only furthered Bakhtin's ideas. She was also inspired by Saussure (1857-1913). Meaning itself is a problematic concept. The structuralists view it to be a fixed entity whereas the poststructuralists like Barthes (1967) disagree by talking about plurality of meanings.

The term discourse is a multifaceted term as it includes both written and spoken forms of communication. Foucault (1926-1984) defines discourse to represent all utterances or texts which have meaning and which have some effect in the real world (as cited in Mills, 1997). Bakhtin (1986) and Foucault (1972) both view meaning to be a flexible, destabilized entity which is continuously constructed through language use in different social contexts. The same stands true for media discourse. Cook (2001) pointed out that a major part of media discourse comprises political discourse and advertisements. Dijk (2009) explained the same idea by discussing how text and talk tend to become naturalized through discursive practices.

Fairclough(1941) presented his ideas on discourse by incorporating two of the Saussurean terms langue and parole. He says that language is a part of society and cannot be separated from it. Therefore, the ideological structures and struggle that take place in any society get displayed through its discourse. His interest in language use motivated him to observe how people exploit language to achieve their purpose which sometimes results in inequality and unrest. He concluded that social practices are discursively shaped through repetition. Taken this way, discourse being a social practice, shapes attitude, behavior and power relations in the society. It, therefore, performs a very significant role in the society. Many of Fairclough's contemporaries viewed language not as a monolithic tool but as an interconnected system of many discourses. Most of them drew upon Foucault's ideas for discovering the functions that discourse performs.

\subsection{Functions of Discourse}

Roman Jakobson (1896-1982) mentioned six functions of discourse namely referential, expressive, conative, poetic, phatic and metalinguistic. The referential function describes a situation, object or the mental state whereas the expressive function relates to the addresser/sender and is usually displayed through the use of interjections. The conative function directly engages the addressee or receiver and is expressed through vocatives and imperatives. The poetic function can be seen in the form of poetry and slogans whereas the phatic function is used in greetings and casual discussions. The metalinguistic function (also known as the reflexive function) is used to describe the language itself. This type of discourse function is almost the same as the poetic function.

\subsection{Media Discourse: A Major Force Behind Ideology Formation}

Newspaper articles, advertisements and speeches are all different forms of media discourse. Gruyter (1985) calls media a major cultural and ideological force responsible for establishing and transforming different ideologies. According to Dijk (1993), media can cause change in ideologies and generate ethnical prejudices. It can even result in ethnic abuse. Kartz (2003) talked about how we absorb media while reading newspapers, checking emails or listening to the news. This is why; Talbot (2007) calls media to be the prime source of understanding the world. Dijk (1988) also said that political discourse may represent group ideologies and other beliefs. By other beliefs he meant a collective text which needs a cognitive interface between party program, personal 
opinions and experiences. He also explained how ideologies are not always explicit as they can be disguised, hidden or implicit, yet it is possible to uncover them by employing the techniques of critical discourse analysis.

Critical discourse analysis views language as a social practice (Fairclough \& Wodak, 1997). Different disciplines suggest different strategies that can be adopted to uncover the relationship between language and power which in so many ways is responsible for social injustice.

Foucault says that no discourse exists in vacuum. It is always situated in a context and is connected with other discourses. Hence, every discourse is linked with discourses in the past. This idea can be understood by using Wodak's (2001) discourse historical approach (DHA). Wodak explains how different discourses and texts have historical links and hence are interrelated.

\subsection{Intertextuality and Textual Relations}

Herbert (2011) also discusses about discourse by mentioning some textual relations for example autotextuality (a relationship of the text with itself both structurally and contentwise), architextuality (the designation of a text as a part of a genre or genres) (Genette, 1997), autogenericity (a form of autotyping in which a text is linked to itself) and intergenericity (the way a text type is linked to another text type or text types).To him, the elements of discourse and social practices are inherent in different but interrelated texts which have deep institutional and social meanings and can aid in understanding the ideologies implicit in one particular text (Candlin \& Maley, 1997).

Barthes combines ideas from psychoanalysis and linguistics for clarifying the concept of a text. He modifies the concept of a sign as he discusses the linguistic as well as non-linguistic signs. Kristeva further elaborates his ideas by saying that intertextual nature of text means its structuration through words and utterances that existed before and will go on existing (as cited in Allen, 2011). She explains the existence of signs on two planes: a horizontal plane and a vertical plane. She further elaborates on how a text belongs to the writing topic and the addressee on the horizontal plane and how it is related to the literary tradition on the vertical plane. Hence to Kristeva, communication is a two-way process. It happens between the text producer and the text receiver and at the same time, it also takes place between the words themselves. Kristeva named this phenomenon as intertextuality for which Bakhtin used the term dialogism.

\section{Research Methodology}

\subsection{Theoretical Framework}

This study examines the linguistic and contextual aspects of media discourse. For investigating the linguistic aspects, Fairclough's three-dimensional model of intertextuality has been incorporated and for investigating the contextual aspects, Halliday's concepts of field, tenor and mode have been included.

Fairclough talks about two types of intertextuality manifest and constitutive. Manifest intertextuality includes other texts in an explicit way as they can be easily recognized through quotation marks, citation, paraphrasing and reporting clauses. This type of intertextuality provides security to the text producer as $\mathrm{s} / \mathrm{he}$ is not held responsible for that particular text as $\mathrm{s} / \mathrm{he}$ is not the text producer rather it aids them in giving off a positive self-image by putting on the label of being objective although the actual purpose for using this practice is to gain hegemonic control.

Sometimes, other texts are incorporated for creating something new without directly referring to the actual source. This results in constitutive intertextuality which makes it very difficult to uncover the ideological structures hidden in the texts. Fairclough (1992) views intertextuality to be a process and suggests that the implicit ideologies in a text can be explored by understanding different stages of this process. These stages are: production stage, distribution stage and consumption stage. He also talks about three important dimensions of critical discourse analysis (CDA): description, interpretation and explanation. He says that there are three levels of interpretation and names them as micro, meso and macro. Micro-level of interpretation includes account of the linguistic aspects of a text. Meso-level analysis includes discursive practices related to the issues of production and consumption whereas the macro-level analysis focuses on the intertextual and interdiscursive elements at a broader scale. This also involves societal trends that affect text production.

Ideology symbolizes practices of the powerful or the dominant class which Dijk calls elites. These practices are accepted, adopted and followed by the powerless and the dominated. Eventually they become naturalized as they become set practices and established norms. Power works at different levels including the order of discourses, types of discourses and actual discourses. Fairclough thoroughly examined classes and power in the capitalist society and pointed out how they were implicitly structured in different types of discourses. According to him, 
they embodied institutional and societal ideologies. Fairclough's ideas are relevant to this study. This is why they have been incorporated in this study.

\subsection{Research Design}

The research is mainly qualitative and lies in the anti-positivist paradigm as it adopts a subjective approach. The researcher's metaphysical subjectivism enabled her to perceive reality through her senses because she wanted to explore how language can be used for achieving certain purposes and how intertextuality in media discourse helps the discourse producers achieve their purpose. This meant finding traces of other sources in the reports explicitly mentioned in the forms of quotations, citations or paraphrasing in the news reports (which Fairclough calls manifest intertextuality) as well as the implicit sources (which he terms as constitutive intertextuality).

\subsection{Data Collection}

The researcher studied political media discourse in the backdrop of Elections 2013 in Pakistan. News reports, interviews and political speeches were used as the data. Four Pakistani English daily newspapers namely The News, The Nation, Daily Times and The Express Tribune were used as the data. First three reports are pre-Elections and the last three reports are post-Elections 2013. News reports were a secondary source of data as they had already been published in books, magazines and newspapers (Kothari, 2004). Intertextuality was examined by exploring the relation of one text with the other (Linda, 2009).

\section{Data Analysis}

The data were analyzed contextually as well as linguistically. Contextual analysis was done by considering the context of the texts whereas linguistic analysis was performed by studying textual and intertextual features. So, the analyses were three-dimensional: contextual, textual and intertextual.

For generating and promoting specific ideas and ideologies, a staple media technique is repetition of these ideas in different ways. For uncovering these repetitive media techniques and for finding out answer to the first research question, the most recurring linguistic features were considered and this was done through textual analysis. To discover answer to question two, generic analysis was carried out (The idea of using generic analysis as a research method was initiated by Fairclough in his book Media Discourse in 1995). No text exists in vacuum, hence the context of each text was also considered and analyzed.

Context was studied by considering field, tenor and mode of communication (Halliday's terms, 1989) whereas text was analyzed by performing linguistic analyses. The contextual analysis helped in understanding the purpose of the communicative event in a context.

A detailed linguistic analysis of the text was carried out by focusing on the features of synonymy, antonymy, repetition of words or phrases and adjectives (The frequency of a particular feature has been displayed in parentheses in Table 2).

Generic analysis focused on the generic structure of the news report or article under study. According to Fairclough (1995), a typical news report follows a typical structure including a headline, followed by a lead paragraph, a satellite paragraph and a wrap-up paragraph. It was explored whether this set structure was followed or violated and the reasons behind doing so were also interpreted afterwards.

For intertextual analysis, three-dimensional model comprising discourse representations, generic types of discourse types and configuration of discourses in the texts was used.

The data appear in the appendix provided at the end. Due to space constraints, full reports have not been mentioned. However, the newspapers' names, authors' names as well as the dates of publication of the reports have been mentioned along with each report. In case, the author was not known, the word 'Anonymous' appears in author's place.

Table 1 below displays the contextual features noticed in the data. 'Field' stands for the topic of the report; 'tenor' represents the relationship between the discourse producer and the discourse receiver whereas 'mode' describes the way of communication. They have been tabulated under the heading Contextual Analysis. Likewise, Table 2 displays the recurring linguistic features of the data. They have been analyzed by considering the most recurring linguistic features under the heading's synonyms, antonyms, repetition and adjectives. They have been given the heading Textual Analysis. Similarly, the features of intertextuality included a study of discourse representations, generic type and configuration of discourses. They have been displayed in Table 3 under the heading Intertextual Analysis. 
Table 1. Contextual features

\begin{tabular}{|c|c|c|c|}
\hline & Field & Tenor & Mode \\
\hline Sample I & $\begin{array}{l}\text { Political matters mishandled by the previous } \\
\text { government. }\end{array}$ & $\begin{array}{l}\text { The President of PML-N addressing the business } \\
\text { community. }\end{array}$ & Written \& spoken both \\
\hline Sample II & Election campaign speech. & $\begin{array}{l}\text { The Chairman of PTI addressing an election campaign } \\
\text { gathering. }\end{array}$ & Written \& spoken \\
\hline Sample III & $\begin{array}{l}\text { Election campaign mechanism of religious } \\
\text { parties. }\end{array}$ & $\begin{array}{l}\text { Religious party leaders expressing their views on the } \\
\text { political scenario due to the forthcoming elections. }\end{array}$ & Written \\
\hline Sample IV & $\begin{array}{l}\text { Tragic incidents due to blasphemy issue and } \\
\text { their effects on political developments. }\end{array}$ & $\begin{array}{l}\text { Senators of the Standing Committee discussing } \\
\text { blasphemy issue. }\end{array}$ & Written \\
\hline Sample V & Politics in Pakistan. & The President of PML-N addressing a rally for elections. & Written \& spoken both \\
\hline Sample VI & Maneuvering of the results of elections. & The author addressing the readers about 1990 Elections. & Written \\
\hline
\end{tabular}

\subsection{Contextual Analysis}

The purpose of the speech in Sample I is to grab the attention of the crowd to get their votes in the forthcoming elections. Hence the speaker, who is a leading politician, vows to make the country great and unreasonably raises the expectations of the crowd. This helps him orient them to vote for him.

Sample II displays the speech by a politician and the party Chairman Imran Khan who is addressing a gathering before the elections. He criticizes the previous government for its ill planning, bad governess and cronyism. He suggests a solution to the problems as well.

Sample III is written and with a third person approach. This shows objectivity on the part of the religious parties. Lack of subjectivity symbolizes absence of true feelings and presence of objectivity exposes the political agenda of the religious parties whose sole aim is to gain political benefits from religiously sensitive statements. The news report in Sample IV details a meeting attended by members of the senate after a tragic incident of blasphemy. Due to seriousness of the topic, the report has been written in indirect speech which is a staple technique for avoiding responsibility.

The text in Sample V is mixture of written and spoken discourse. The written part displays seriousness of the situation and the formal obligation of the speaker whose responsibility is to convey his party's message to the voters whereas the spoken part is to establish a close personal, emotional connection with the addresses.

News report in Sample VI is through and through a written discourse which symbolizes seriousness as well as objectivity on the part of its author. The third person approach helps the author remind the readers of the maneuvering done by the then government and at the same time, avoid taking any blame. The prominent use of negative adjectives helps the author convey criticism of the policies of the government and the third person approach aids him avoid any blame.

Table 2. Textual features

\begin{tabular}{|c|c|c|c|c|}
\hline & Synonyms & Antonyms & Repetition & Adjectives \\
\hline Sample I & $\begin{array}{l}\text { said/spoke, } \\
\text { highlighted/reiterated, agenda } \\
\text { of progress/path of } \\
\text { progress/road to progress }\end{array}$ & - & $\begin{array}{l}\text { Support (4), Path/road to progress (6), } \\
\text { reiterated (3), PML-N (10), Business } \\
\text { community (13), Electricity crisis (6), } \\
\text { development in the country (4) }\end{array}$ & $\begin{array}{l}\text { Twin (2), experienced } \\
(5), \text { soft (1), important } \\
\text { (1), former (5) }\end{array}$ \\
\hline Sample II & Make, establish & - & $\begin{array}{l}\text { Prosperous Pakistan (4), Lead a revolution } \\
\text { (3), System of justice (6), Humanity (5), } \\
\text { Islamic welfare state (4), Dictatorship (3) }\end{array}$ & $\begin{array}{l}\text { Major, Islamic, } \\
\text { Prosperous }\end{array}$ \\
\hline Sample III & - & Unity/solo & $\begin{array}{l}\text { Religio-political (5), seat adjustment (5), } \\
\text { forthcoming elections (6), religious } \\
\text { parties/forces (4), leadership (3), ideology(4) }\end{array}$ & Solo \\
\hline Sample IV & Misuse/abuse, & - & $\begin{array}{l}\text { Blasphemy issue (5), false (3), blasphemy } \\
\text { law (4), abuse of law (4), tragic incident (3), } \\
\text { senators (4) }\end{array}$ & $\begin{array}{l}\text { False (2), adjoining } \\
(1) \text {, blasphemous }(1) \text {, } \\
\text { small (1) }\end{array}$ \\
\hline Sample V & $\begin{array}{l}\text { Promised/vowed, end load- } \\
\text { shedding/end power outrage, } \\
\text { looting/plundering, provision } \\
\text { of power/power generation, } \\
\text { real force/real asset }\end{array}$ & $\begin{array}{l}\text { Paralyzing } \\
\text { business/strengthening } \\
\text { economy, looting } \\
\text { money/provision of jobs }\end{array}$ & $\begin{array}{l}\text { Said (10), the fate of Pakistan (9), PML-N } \\
(8), \text { youth ( } 7), \text { loan (3), real asset (5), } \\
\text { load-shedding (6) }\end{array}$ & $\begin{array}{l}\text { Real, small, thousands, } \\
\text { short, soft, five-year }\end{array}$ \\
\hline Sample VI & Dislodge/ouster/ thwart & - & $\begin{array}{l}\text { Military establishment ( } 7) \text {, dole out money } \\
\text { (6), PPP (8), elections (8), government (6), } \\
\text { caretaker setup (5), }\end{array}$ & $\begin{array}{l}\text { Beleaguered, harsh, } \\
\text { high, one-line, } \\
\text { disastrous, dirtier }\end{array}$ \\
\hline
\end{tabular}




\subsection{Textual Analysis}

The lexical items used in Sample I show that most of them belong to the same semantic field and deal with progress of the business community and development of the country. Most of them refer to the business community and infra structure of the country. The metaphor 'Asian tiger' refers to the country in order to show the intention of making it very strong. Repetition of these words is a form of autotextuality (Wodak's term, 2001) and helps to get public attention and present a very rosy picture of the future just to convince people to vote for PML-N as it is capable of changing the fate of the country. Most of the lexical items used in Sample II are positive. So, they portray a hopeful future for the readers.

The lexical items used in Sample III help to understand the basic ideas. This news report appeared on the front page under the masthead which signifies its importance. Mostly, negative adjectives have been used in Sample IV. Hence, the discourse used here is replete with manifest intertextuality and can be seen through phrases like blasphemy law, legal consequences, abuse of law and tragic incident. It seems to be the official discourse of law through which a bleak picture has been painted.

Apart from the words displaying the prevailing issues like load-shedding and unemployment, a lot of lexical items promising a better future have been used in Sample V. Youth have been considered the asset of the country and there are vows to provide soft-loans to them but it is very vague and seems to be a mere enticing technique for attracting them as no concrete plan has been put forward. Nawaz Sharif goes off the topic and starts blaming others. He discusses troubling topics that are a concern of his addresses such as load-shedding, darkness, looting and plunder. And through them, he tries to catch the attention of commoners. The theme of the report in Sample VI is to expose the dirty and shady deals that were made to manipulate the results of 1990 general elections. So phrases like horse-trading, dole-out money and dislodge the PPP government have been used to describe the situation. They are a form of manifest intertextuality. It can be seen from all samples that the same ideas were projected through these linguistic features: synonymy, antonymy, repetition and adjectives. It can be easily seen from the frequency of these features that they were the most recurring ones in the data which can be used as an effective tool for injecting and infusing political ideologies.

Table 3. Intertextual features

\begin{tabular}{|c|c|c|c|}
\hline & Discourse Representations & Generic Type & $\begin{array}{l}\text { Configuration of } \\
\text { Discourses }\end{array}$ \\
\hline Sample I & $\begin{array}{l}\text { (i) The President of PML-N, (ii) members of PML-N, (iii) } \\
\text { business community, traders, industrialists (iv) youth (v) } \\
\text { masses (vi) ex-Army Chief \& ex-President Pervaiz } \\
\text { Musharaf (vii) ex-President Asif Ali Zardari, (viii) the news } \\
\text { reporter (ix) Shahbaz Sharif }\end{array}$ & A typical newspaper report & Liberal \& political \\
\hline Sample II & $\begin{array}{l}\text { (i)The President of PTI (ii) members of PTI (iii) a reporter } \\
\text { who participates during the talk }\end{array}$ & A typical newspaper report & Marxist \& liberal \\
\hline Sample III & (i) Different religious party leaders (ii) the reporter & $\begin{array}{l}\text { A newspaper report without a minor } \\
\text { heading }\end{array}$ & Political \& religious \\
\hline Sample IV & $\begin{array}{l}\text { (i) Members of the Senate Standing Committee (ii) The } \\
\text { reporter }\end{array}$ & $\begin{array}{l}\text { A newspaper report without a minor } \\
\text { heading and wrap-up paragraphs. }\end{array}$ & $\begin{array}{l}\text { Descriptive \& narrative } \\
\text { discourses }\end{array}$ \\
\hline Sample V & $\begin{array}{l}\text { (i) The President of PML-N (ii) party workers (iii) youth (iv) } \\
\text { the unspecified news reporter and the correspondent }\end{array}$ & $\begin{array}{l}\text { A newspaper report without a } \\
\text { wrap-up paragraph }\end{array}$ & Marxist \& Liberal \\
\hline Sample VI & $\begin{array}{l}\text { (i) The reporter. (ii) General Ziaul Haq (iii) General Aslam } \\
\text { Baig (iv) Asad Durani (v) ex-President Ghulam Ishaq Khan }\end{array}$ & $\begin{array}{l}\text { A newspaper report with major and } \\
\text { minor headlines switched together }\end{array}$ & $\begin{array}{l}\text { Liberal (with traces of } \\
\text { expository writing) }\end{array}$ \\
\hline
\end{tabular}

\subsection{Intertextual Analysis}

There is one prominent, explicit voice in Sample I and it is of the leader of PML-N. Rest of the voices have been back grounded. The report has the typical structure of a newspaper report. The use of indirect speech indicates formality as the reporter distances himself from the report. The major headline is a direct quotation which conveys the exact message of the main speaker. Hence, the major heading is a form of manifest intertextuality. It is followed by a minor headline. Both are catchy and attract the readers' attention at once. The use of simple words in the minor headline makes it easy for the common people to understand and hence, seems to be effective. The lead paragraph summarizes the whole report whereas the satellite paragraphs further elaborate the information. There are no wrap-up paragraphs. This causes the report to end abruptly. Fairclough (1995) calls such a report a 'hard' one. The purpose of using such hard discourse is to make people aware of harsh realities. 
The speaker belongs to the capital-owning bourgeois class which is obvious from the discourse strategies that he employs as he talks about dragging the country out of all challenges and crises and also wows to overcome the problems of common people like load shedding, unemployment, affordable housing and easy-to-manage loan schemes.

In Sample II, the chairman of PTI's voice is most prominent. The background voices include 70 thousand abducted people, all members of PTI and the audiences. This backgrounding is a form of constitutive intertextuality. The reporter uses direct speech most of the time which puts his own voice in the background. The headline gives a statement and the minor headline reinforces it. Both are catchy. The lead paragraph as well as the satellite paragraphs further explain the same idea. This repetition helps the author strengthen the point. For building a strong rapport with the audience, the speaker mixes formal discourse with the informal one. It helps him create a democratic look of the report. The same is enhanced by using features of the Marxist liberal discourse.

The reporter's voice is prominent in Sample III also as his name is mentioned. He establishes democracy by including the opinions of different religious party leaders. The use of formal language helps the author uncover the stark underpinnings in the religious discourse whereas the use of indirect speech helps him attain and retain control. It also indicates that the original ideas might have been tempered. There is just a major headline as the minor heading is missing. This feature explains the content in its entirety.

In Sample IV, the author's voice is the most prominent feature which is obvious from the use of indirect speech in most of the sentences. This is a form of constitutive intertextuality which gives full control to the author and he is able to manipulate the discourse. Moreover, absence of a minor heading makes it to-the-point and direct and the use of formal language makes the report look realistic and serious which is further elaborated in the satellite paragraphs. The absence of wrap-up paragraphs causes the report to end abruptly which adds to the seriousness of the report. This has been done deliberately as it is a set technique in media discourse for making the readers realistic. The discourse genre that is the most obvious is narrative and it helps to establish order in terms of organization and eventually gives the report a smooth, regular look.

The most prominent voice in Sample V is that of the party chairman Nawaz Sharif. The heading of the news report is a direct quote. Hence the report starts with manifest intertextuality. The backgrounded voices include the party workers and the news reporter. The reporter indirectly controls the discourse through the use of indirect speech which has been employed throughout the report except for two sentences. This helps the author exercise his power and change the discourse.

The report contains a major headline followed by a minor headline. The lead paragraph explains the headline and the satellite paragraphs further elaborate it. There is no wrap-up paragraph because the author might be thinking that he has explained the issue completely and any more effort might be redundant. There is a mixing of genres as informal, conversational and a formal style all have been used. This creates intergenerecity in the text. This helps the reporter give a democratic look to the report. The same has also been achieved by employing the ideological state apparatuses (Althusser's term) through mixing of the features of the Marxist and the Liberal discourses.

The report in Sample VI has only one active voice and that is the voice of the reporter. There are four passive voices including General Ziaul Haq, General Aslam Baig, Asad Durani and the ex-President Ghulam Ishaq Khan. This gives full control to the reporter which he exercises through the reverse order of major and minor headings. Overall, the intertextual features are constitutive because most of the voices are implicitly mentioned. The lead paragraph briefly talks about the news which is further elaborated and strengthened in twelve satellite paragraphs. Mainly, features of expository writing have been incorporated and its purpose is to portray a realistic picture for the readers.

\section{Discussion}

This article has investigated intertextuality in media discourse. The main purpose was to explore how media discourse shapes and moulds public opinion. It also aimed at exploring whether the linguistic devices in media discourse merely serve the purpose of providing stylistic variation or also have some serious effects on their readers.

The data were collected through documents and records. The researcher started objectively. The most prominent and active voices were those of the newsmen and the speakers of the discourses under scrutiny. Though all the samples included a web of voices, yet the author's own opinion was not explicitly voiced. This phenomenon signifies the presence of constitutive intertextuality in all the reports under scrutiny.

The analyses reveal that the issues of public concern can be used as an effective technique because they help the discourse producer grab public attention by sensitizing them. 
In the intertextual analysis section, it can be seen that though the reporter's voice is implicit, yet s/he seems quite vocal through framing of the headlines and it is solely his/her choice about how to frame and present them. By skipping some of the features of a typical news report and by shuffling the order of its elements, the author can achieve his/her purpose. Moreover, repetition has also been used through the newspaper structure. It can be seen that same ideas have been repeated many times through the minor heading, satellite paragraphs as well as wrap-up paragraphs.

The analysis also revealed that indirect speech was employed most of the time. Repetition of ideas in the text serves as a reminder. Eventually, it starts forming and shaping public opinion. Thus, it can be used a tool for controlling common people's minds. The reporters use this tool effectively for generating ideologies and shaping public opinion. They can play with it and manipulate the readers. This becomes a métier with experienced, skillful reporters over time. The use of indirect speech enables an author add and blend his/her ideas into the actual text in an undetectable way. It also causes a change of version which blurs the boundaries and creates layers of meanings. And this is the basic tenet of intertextuality.

The linguistic analyses disclose how certain linguistic strategies are used as a form of repetition. Hence, lexical items from the same semantic field were discursively used through the features of synonymy, antonymy and adjectives. According to Leech (1974 \& 1981), people do not rely on literal meaning only as they consider their own perceptions as well. Repetition of same ideas makes them seep and settle down in the minds of the readers in subtle ways. Hence, repetition was used by the discourse producers as a technique for instilling their ideas into the minds of the discourse receivers.

Dijk (2000) says that ideology is expressed through discourse and serves as the basis for social and cultural representations. He also says that politicians project two types of ideologies in their text and talk: professional and practical. He also talks about their socio-political ideologies to which they stick as a group. Most of them try to project their national ideology which is a common strategy for gaining popularity and win the people over. Socio-political ideologies are usually disguised in the form of national or cultural ideologies which are used interchangeably.

The generic analysis of discourse types of the texts reveals that the technique of merging genres together was done implicitly. In order to create the desired effects, the discourse producers were referring to some events from the past. This was done discursively and it indicates intertextuality. The study also made it clear that the politicians continuously refer to the past events for backing and authenticating their statements and sometimes for creating dramatic effects.

\section{Conclusion}

The analyses revealed that almost all politicians displayed the ideology of nationalism in their discourse by using expressions like progress of the country, peace and harmony, establishment and national responsibility. Renan (1823-1892) was of the view that a collective, national identity is necessary for a nation to develop. However, the politicians exploit this idea only to gain popularity but this is also true that politicians are the leaders and that political discourse affects the lives of people coming from all backgrounds, races and ethnic origins. It also influences and shapes their behaviors. Fairclough mentions that in media discourse, usually a combination of official and colloquial discourses is used. This is done on purpose because such an arrangement is appropriate for routine general discourse, as the readers can relate with it. The analyses show that specific elements from different discourses were combined in the texts creating hybrid discourses, for example, the Marxist political discourse was combined with the liberal political and religious discourses.

From Marxist perspective, power displays itself in the form of dominant discourses which gradually establish power relations among people and states. The interface between different discourses causes hybridization which affects ideological understanding of the readers.

Generic analysis of discourse types shows that the Pakistani news reporters do not strictly follow any schematic pattern. They use a number of ways for making a headline which Fairclough terms as 'nucleus' sometime it has both major and minor headlines. Same is the case with different paragraphs.

Intertextuality is present in every text especially in the political discourse. It has a direct connection with the general public. So, no text should be understood only at the surface level, because hidden agendas are generally achieved through deeper, implicit structures.

\section{Acknowledgements}

The researcher feels grateful to her mentor Dr. Muhammad Uzair for his tireless support throughout her academic endeavor. She also owes heartiest thanks to her entire family, especially her brother Sulman Aslam for his logistic 
support and sincere concern. Last but not least, she would like to express her gratitude to all her peers at NUML for their assistance and constructive comments.

\section{References}

Allen, G. (2000). Intertextuality. London: Routledge. https://doi.org/10.4324/9780203131039

Allen, G. (2003). Ronald Barthes. London: Routledge, 11 New Fetter Lane, London EC4P 4EE.

Bakhtin, M. M. (1981). The Dialogic Imagination (trans. Caryl Emerson, Micheal Holoquist \& edit Micheal Holoquist). The University of Texas Press Austin, USA.

Bakhtin, M, M. (1986). Speech Genres and Other Late Essays (trans. Vem W. MacGee. edit. Caryl Emerson \& Michael Austin). USA.

Barthes, R. (1967). The Death of The Author (trans. Richard Howard). London, UK: Macmillan.

Bulman, G. A. (2007). Staging Words, Performing World: Intertextuality and Nationin Contemporary Latin American Theatre. Rosemont Publishing and Printing Corporation.

Cook, G. (1990). Discourse. Oxford: Oxford University Press.

Cook, G. (1992). The Discourse of Advertising. London: Routledge.

Fairclough, N. (1989). Language and Power. Edinbrough, UK: Longman Group Limited.

Fairclough, N. (1992). Discourse and Social Change. Cambridge, UK: Polity Press. https://doi.org/10.1177/0957926592003002004

Fairclough, N. (1992a). Discourse and Text: Linguistic and Intertextual Analysis within Discourse Analysis. Discourse \& Society, 3(2), 193-217. https://doi.org/10.1177/0957926592003002004

Fairclough, N. (1995). Media Discourse. London, the Hodder Headline Group.

Fairclough, N. (1995a). Critical Discourse Analysis: The Critical Study of Language. London, UK: Longman Group Limited.

Fairclough, N. (2003). Analyzing Discourse: Textual Analysis for Social Research. London: Routledge. https://doi.org/10.4324/9780203697078.

Fairclough, N. (2006). Language and Globalization. London: Routledge.

Foucault, M. (1972). The Archaeology of Knowledge. London: Routledge.

Foucault, M, P. (1966). The Order of Things: The Archeology of Human Sciences. Paris:Gallimard.

Foucault, M, P. (1995). Discipline and Punish: The Birth of the Prison (trans. Alan Sheridan). New York, USA: Random House, Inc.

Genette, G. (1972). Narrative Discourse: An Essay in Method. Cornwell University Press.

Genette, G. (1997). Paratexts: Thresholds of Interpretation. Cambridge University Press. https://doi.org/10.1017/CBO9780511549373.

Gruyter, D. (1985). Discourse and Communication —Research in Text Theory (edit. van Dijk: Walter de Gruyter \& Co.) Berlin, Germany.

Halliday, M. A. K. (1994). Introduction to Functional Grammar (2nd ed.). London: Edward Arnold.

Halliday, M. A. K. (2002). Linguistic Studies of Text and Discourse (edit. Webster, J. J.). Bodmon, Cornwall: MPG Books Ltd.

Hebert, L. (2011). Tools for Text and Image Analysis: An Analysis to Applied Semiotics (trans. Tabler, J.) Quebec University Press.

Jakobson, R. (1960). Closing Statements: Linguistics and Poetics, Style in Lnguage. New-York: T. A. Sebeok.

Jakobson, R., \& Halle, M. (1956). Fundamentals of Language. The Netherlands: Mouton Co.

Kartz, H. (2003). The Media Handbook. Lawrence Erlbaum Associates, Inc.

Kothari, C. R. (2004). Research Methodology: Methods and techniques. New Age International (P) Ltd.

Kristeva, J. (1986). The Kristeva Reader (edited. Toril Moi). New York: Columbia University Press.

Kristeva, J. (2001). Hannah Ardent: Life is a Narrative (trans. Collins, F.). University of Toronto Press.

Mills, S. (1997). Discourse: The New Critical Idiom. London: Routledge. 
Talbot, M. (2007). Media Discourse: Representation and Interaction. Edinbrough: Edinbrough, University Press Ltd.

Van Dijk, T. A. (1998). Ideology: A Multidisciplinary Approach. London: SAGE Publications.

Van Dijk, T. A. (2009). Society and Discourse. London: Cambridge University Press. https://doi.org/10.1017/CBO9780511575273.

Wodak, R., \& Meyer, M. (2001). Methods of Critical Analysis. London: SAGE Publications.

\section{Appendix:}

\section{Sample 1}

(The News, April 12,2013)

\section{By: Anonymous}

\section{Nawaz vows to make 'Asian tiger' dream come true}

Says only PML-N has agenda of progress

ISLMABAD: Pakistan Muslim League Nawaz (PML-N) President...Asian tiger'...after winning the elections... addressing business community...previous government filled their pockets... Pervaiz Musharraf is responsible for electricity problem...premiership was not his destination... rivals are living in fool's paradise... Pakistan needs experienced leadership...PML-N will take the country where it was once...eradicate corruption....after coming into power...soft loans for the youth...PML-N would bring a revolution... road to progress...soft loans will be given as ... future of Pakistan.

\section{Sample II}

(The Nation, May 6, 2013)

\section{By: Anonymous}

\section{Imran Khan pledges to make Pakistan Islamic welfare state}

Says Nawaz can't lead...to establish prosperous Pakistan

MIANWALI: PTI Chairman Imran Khan pledged to...Islamic welfare state...the political parties did not do anything...how would we be able to turn fate...while addressing an election campaign....introduce a system of justice....caste and creed and free...clutches of US...slogan 'Pakistan ka Matlab kia'...criticizing the past governmtnt...change in the system would be brought...PTI would sweep...you can't lead ...hide behind bullet-proof glass...revolution taking place....although Khan believes to win...critics think he can secure only 10 30 seats...make him kingmaker ...coalation.

\section{Sample III}

(The Express Tribune, March12, 2013)

\section{By: Arshad Bhatti}

\section{Religious parties in solo flights}

LAHORE: The term 'unity' considered to be the hallmark of Muttahida Majlis-e-Amal...has lost its relevance...groups call for reinforcement of Islamic Shariah...but their strategies make them dependent on other...mainstream parties which are PTI, PPP and PML-N...Jamaat-e-Islami wants a seat adjustment with PML-N and so does Jamait Ulema-e-Islam Fazl...JI had commitment with PTI but later on backed out...Maulana Fazlur Rehman talked to media at Allama Iqbal International Airport ...but religious parties are not fighting a battle of ideology...

\section{Sample IV}

(Daily Times, June 11, 2013)

\section{By: Asim Qadeer Rana}

\section{Blasphemy issue MPs for action against false accusers}

ISLAMABAD: Members of the Senate Standing Committee on National Harmony...stressed...leveling...allegations in blasphemy law...legal consequences...country's laws...members were attending...briefing on...Badami Bagh tragedy...improve law...absue and misuse of blasphemy 
law...Joseph Colony...267 Christian families were living.... mob attacked...set the area on fire...vandalized the property of all inhabitants...committee....attended by Senators Khalida Perveen, Amar Jeet, Kamran Michael and Heman Das.

\section{Sample V}

(The News, May 14, 2013)

\section{By: The Correspondent}

\section{May 11 is the day to change Pakistan's fate: Nawaz}

Says youth real force of PML-N; people don't bother ill-minded ads against PML-N

MANDI BAHAUDDIN: Pakistan Muslim League- Nawaz (PML-N) President... May 11 is not the election day only... 'May 11 is the day to change the fate of Pakistan...' the fate of Pakistan...short address to a rally...to steer country out of darkness...end load shedding...PPP was involved in looting and plunder...only PML-N can end problems...youth real asset...soft loans would be given to them...to prevail democracy..strengthen economy...other parties...publishing advertisements...PMN-L would overcome darkness in three years... thousands of jobs would be created...'Other parties are only publishing advertisements...' distribution companies would be privatized for better performance.

\section{Sample VI}

(The Nation, Aug 30, 2013)

\section{By: Tahir Mehdi}

An overview of 1990 general elections

The game gets dirtier

Gen Ziaul Haq's one-line addition to Article 58...1973 Constitution...empowered the President to dismiss govt...Article 58(2b) ...used twice...President Ghulam Ishaq Khan...dismissed beleaguered Benazir's govt...Operation Midnight Jackal...horse-trading and shifting party loyalties...harsh military establishment...Asghar Khan's Tehreek-i-Istaqlal... Tehreek-i-Nafaz-i-Fiqah-i-Jafria... Gen (R) Aslam Baig and Gen(R) Asad Durrani acted in violation ... doled out money...loyalties of military establishment...manipulation of results...no seat were reserved for women...hah to wait till $2002 \ldots$.return of these seats.

\section{Copyrights}

Copyright for this article is retained by the author, with first publication rights granted to the journal.

This is an open-access article distributed under the terms and conditions of the Creative Commons Attribution license (http://creativecommons.org/licenses/by/4.0/). 